\title{
Young Stakeholders' Perception of Public Companies Responsibility: An Empirical Study on Business-to-Customer Markets*
}

\author{
Cecilia Casalegno, Elena Candelo \\ University of Turin, Turin, Italy
}

\begin{abstract}
The present research aims to investigate business-to-customer Italian public companies and their relationship with young stakeholders. The focus is to analyse the correlation between young stakeholders' perception of company environmental and social sustainability and the market capitalisation. The approach of the present research has been used to structure the literature and to conduct an empirical analysis on a sample of public companies chosen among the Italian larger 150 in terms of market capitalisation. Through a qualitative research based on focus groups and individual interviews, a sample of 33 public companies has been selected and tested by using an online survey of 420 Italian youth. The analysis of firms' young stakeholders' responsibility perception has taken to confirm those authors and managers sustain that the more the firm market capitalization is, the more the organization is perceived as responsible.
\end{abstract}

Keywords: corporate social responsibility (CSR), brand communication, sustainability, market capitalization, stakeholder perception, SERVPERF, young stakeholder

\section{Introduction}

Academic authors and managers consider responsible, ethical, and sustainable behaviours to be effective levers companies can adopt to reach their stakeholders, in general, and to meet their consumers' needs successfully (Torres, Bijmolt, Tribo, \& Verhoef, 2012; Lopez-De-Pedro \& Rimbau-Gilabert, 2012; Vallaster, Lindgreen, \& Maon, 2012; Kuepfer \& Papula, 2010; Macleod, 2001; Mohr, Webb, \& Harris, 2001). All the actions conducted within the above mentioned fields are commonly defined with the name of corporate social responsibility (CSR) and have started being actively implemented by companies for the last decades (Candelo, Casalegno, \& Civera, 2014). Moreover, it is increasingly important being transparent and frequently communicating with stakeholders; in this way they know about the social and environmental firm's commitment and its willingness to share its values with the local population. According to the recognized interdependence between business and society (Porter \& Kramer, 2006; 2011), today is growing a perspective

\footnotetext{
* Although this paper is based on collaboration, Prof. Elena Candelo is to take credit for paragraphs named "Stakeholders Perception of CSR: Brand and Communication Strategies" and "Analysis and Discussion of Results", Dr. Cecilia Casalegno is to take credit for paragraphs "Introduction", "Research Method and Design", and "Conclusions".

Cecilia Casalegno, Ph.D., reseacher and lecturer, Department of Management, University of Turin, Turin, Italy.

Elena Candelo, associated professor, Department of Management, University of Turin, Turin, Italy.

Correspondence concerning this article should be addressed to Cecilia Casalegno, Corso Unione Sovietica 218 bis, 10134 Turin, Italy. E-mail: cecilia.casalegno@unito.it.
} 
of corporate responsibility and stakeholders engagement whereby stakeholders themselves should be actively committed in corporate life and take their duties for company success (Candelo et al., 2014). So companies have to craft social initiatives appropriate to their own strategies, in order to create the desired perception in stakeholders' minds. In this way, the CSR, approached strategically, generates opportunities, innovation, and competitive advantage, while solving pressing social problems (Porter \& Kramer, 2006). This perspective produces significant changes in CSR management, mainly to the extent that stakeholders have the right to judge actions and mistakes of a company and in the same way to reward the company itself with greater loyalty and brand recognition, expressly in case of good ethical performances. Nowadays CSR is largely being strengthened to include a concrete set of tools and planned activities addressed to solve social and environmental issues with positive repercussions on the reference community. It is, in other words, a way of positioning business and relations with community by using ethical, environmental, and social drivers (Macleod, 2001; Mohr et al., 2001; Kuepfer \& Papula, 2010). Despite the large literature concerning the CSR, a little has been told about the firm responsibility perception of young people in consumer markets. The present paper aims to investigate the relationship between firms' CSR efforts and young stakeholders' perception.

\section{Stakeholders Perception of CSR: Brand and Communication Strategies}

In the context of responsibility, it clearly appears that the more the social, environmental, and ethic activities are connected to the company brand, the more the organization can mutually benefit from them, even as a form of public relations or advertising and promotion (Porter \& Kramer, 2006).

The corporate brand associations, including beliefs and feelings that individuals mature in relation to company, specifically considering its ability to have an ethical and responsible behaviour, are key elements for brand value. In order to make effective corporate associations, it becomes essential to adequately communicate commitments and relevant actions, in relation to reassurances on quality and healthiness of products, to information about reduction of environmental impact, to transparency about human rights respect, to existence of positive relationship with local communities, to attention on the supply chain, and to adoption of codes of conduct and standards certifications. These intangible assets, represented by the reputational capital, are the basis in improving brand perception and the use of these assets in branding strategies. If managed, it will create a virtuous cycle building trust and increasing corporate brand value. In this sense, it is an understatement to say that investments in CSR have positive impact on the long-term competitive advantage in differentiating products and services (Demetriou, Papasolomou, \& Vrontis, 2009). The success of a corporate brand is determined by a set of requirements (Aaker, 2004; Aaker \& McLoughlin, 2009), which also include corporate sustainability (Blombäck \& Ramírez-Pasillas, 2012). In this sense, researches show that stakeholders base their opinion about brands also on company's ethics and on company environmental, social, and economic sustainability, confirming that these issues are important parts of the company reputation. To gain these purposes, it is extremely necessary to have consistency between values associated with the corporate brand and those transmitted by the behaviour of the company as a whole. Any dystonia between companies' behaviour and brand reputation will be immediately put in evidence and used against the company itself (Aaker \& McLoughlin, 2009; Wheeler, 2012; Christodoulides \& Jevons, 2011), impacting the financial results of the company (Werther \& Chandler, 2005). In this sense, the long-term competitive advantage creation and the company responsibility are becoming increasingly interconnected as well. 
From the brand strategy side, the activities carried out within CSR should somehow be made visible inside and outside the company to create brand associations. Not necessarily the choice is communicating through the heritage media, but the generation of a positive word-of-mouth represents a free and effective solution. This is the case of strategic philanthropy (Porter \& Kramer, 2006) firms implement to get visibility and benefit in a win-win situation (for the company and for the society itself). In some cases, news is voluntarily diffused only within the company with the goal of generating positive word-of-mouth and of stimulating social legitimacy using a proper stakeholders' expectations management.

Corporate brand management has therefore to incorporate CSR activities into its strategies with long-term goals, taking into account the society evolution. But are companies brand strategies really effective in building this kind of perception also by means of the communication of sustainable activities? Do stakeholders really perceive the social responsibility activities? If yes, how do they perceive them? Are stakeholders conscious or unconscious of their own perception? To address these questions, companies have to concern the feedback elements and they have to be extremely sensitive on stakeholders' reactions. Stakeholders must be noticed about the organization culture in order to feel linked to the company and communication strategies, based on coherence. They are the driver to create the right reputation, based on the concept of responsibility. According to this perspective, over the last years, the firm responsibility has become the most powerful internal and external way of communicating homogenization. In this scenario, the company is asked to put everything together and make it works (Schultz, Tannenbaum, \& Lauterborn, 1994) and do it with coherence, introducing in this way one of the premises of the so-called integrate marketing communication (Schultz et al., 1994; Collesei \& Ravà, 2008; G. E. Belch \& M. A. Belch, 2009) which has to be directly connected to what can be called integrated firm communication (Romoli Venturi, Casalegno, \& De Palm, 2014) that goes beyond traditional marketing goals. Companies need to share values concerning their responsibility, not only under the communication form but through concrete, valuable, and sustainable strategies: They need to strengthen the concept both as communication and strategy and bring it to a new level, the one of social innovation and corporate shared value (CSV) (Porter \& Kramer, 2011). This is a profitable strategy moving beyond business and social concerns trade-off and it is about the sum of policies and practices that can buster companies' competitive power meanwhile they improve community economic and social conditions. Moreover, the Rep Trak 100 - Global Report (2013) has proven that the more a public company reaches a high degree of reputation (also composed by the concept of sustainability), the more its market capitalization will be.

Since one of the aims of the paper is to investigate how the firm communication can impact stakeholder corporate responsibility perception, the literature review of the term can help in order to find major dimension that can affect the stakeholder perception. Despite the difficulties in finding measures, Schianetz and Kavanagh (2008) asserted that the use of the term sustainable, linkable to the one of CSR, has a meaning, if it can be measured. Moreover, indicators can begin a "learning process" able to help local stakeholders to identify firms' sustainable development goals and managerial strategies. In addition, sustainability indicators are fundamental in order to introduce sectorial consideration in terms of environment (Rebollo \& Baidal, 2003). The environmental aspect prevails at a national level, while at a local one, it is useful to add sustainability economic and socio-cultural dimensions (Rebollo \& Baidal, 2003).

\section{Research Methodology and Design}

The present research aims to analyze Italian public companies and their Italian young stakeholders, aged 
between 18 and 30 years, considering people who began adult at the beginning of the 21 st Century. It is to underline that in Italy in the past, culturally, the growth and the weight of social concerns have always been more connected to the pressure and the influence of religion, which have played a significant role even in the political debate and process towards the creation of a welfare-state. Today within the growth of CSR and increasing concerns about whether or not businesses can be conducive to society well being, Italian companies are seeking to introduce these practices as more formalized part of their core business activities, considering the youth's increasing interest of social concerns.

Accepting the importance of the concept of responsibility for firms and their capacity to communicate about it, the aim of the present research is to answer the following two questions:

Q1: In which business-to-customer industries, public companies are perceived to be more involved in the issue related to the environmental, economical, and social sustainability?

Q2: Considering public companies, does there exist any correlation between young stakeholders' perception of company environmental and social sustainability and the market capitalisation?

In order to answer the two questions, the methodology has been based both on qualitative and empirical analysis. In a first step, the focus has been related to investigate the first 150 Italian public companies in business-to-customer markets, concerning how much they have known about their involvement in the territory. The analysis was conducted to understand from people - through focus groups and qualitative interviews, considering a sample of 70 Italian people aged between 20 and 50 years (Table 1), considering the age proximity to the analyzed people and business knowledge level-how much they were aware of the social activities of the most capitalized Italian companies.

Table 1

Interviewed People

\begin{tabular}{lc}
\hline Role & Quantity \\
\hline Mass market audience & 30 \\
Small companies managers & 10 \\
Medium companies managers & 5 \\
Large companies managers & 5 \\
University students & 10 \\
Consultants and experts in firm strategy & 10 \\
\hline
\end{tabular}

Results indicated the following 33 public companies (Table 2).

Table 2

The Top 33 Italian Public Companies in Terms of Their CSR Perception (Listed by 2013 Market Capitalization)

\begin{tabular}{ll}
\hline Rank & Top 33 Italian public companies \\
\hline 1 & Luxottica \\
2 & Telecom \\
3 & Campari \\
4 & Fiat \\
5 & Pirelli \\
6 & Parmalat \\
7 & Tod's \\
8 & Autogrill \\
9 & Delonghi \\
\hline
\end{tabular}


Table 2 continued

\begin{tabular}{|c|c|}
\hline Rank & Top 33 Italian public companies \\
\hline 10 & Rcs \\
\hline 11 & Amplifon \\
\hline 12 & Piaggio \\
\hline 13 & Indesit \\
\hline 14 & Geox \\
\hline 15 & Safilo \\
\hline 16 & L'Espresso \\
\hline 17 & Mondadori \\
\hline 18 & Juventus Fc \\
\hline 19 & Poltrona Frau \\
\hline 20 & Damiani \\
\hline 21 & Basic Net \\
\hline 22 & Seat Pg \\
\hline 23 & Tiscali \\
\hline 24 & Piquadro \\
\hline 25 & Beghelli \\
\hline 26 & As Roma \\
\hline 27 & Il Sole 24 Ore \\
\hline 28 & Natuzzi \\
\hline 29 & Stefanel \\
\hline 30 & SS Lazio \\
\hline 31 & Zucchi \\
\hline 32 & Centrale Latte Torino \\
\hline 33 & Bialetti \\
\hline
\end{tabular}

Consequently, an adaptation of the SERVPERF questionnaire (Cronin \& Taylor, 1992) has been taken into account in order to test stakeholders' perception of responsibility of the sample. The 33 firms have been tested the main following five dimensions responsibility which can emerge from the literature analysis: (1) firm involvement on local pollution; (2) firm involvement on local job creation; (3) firm contribution on local wellness development; (4) firm strategic human resource management and respect based communication; and (5) firm external communication based on the willingness of sharing values with stakeholders. The online questionnaire was administered to a sample of 420 people aged between 18 and 30 years. The perception of the five dimensions has been analyzed through the use of the Likert scale ( $1=$ Disagree; $5=$ Strongly agree $)$, so respondents have been asked to express their agreement concerning the above dimension for each of the 33 firms already considered in the first part of this present research. In order to evaluate the stakeholder CSR perception for the most known industries, the followings have to be evaluated:

(1) For every firm, the mean $(P)$ of sample judgments $(n=420)$ for every tested responsibility dimension is:

$$
P=\frac{\sum_{J=1}^{n} P j}{n}
$$

(2) For every firm, the mean of means of the five dimensions has been used in order to break up the concept of responsibility. Considering that a five point Likert scale has been used, a result around 3.00 can represent an acceptable level of perception of responsibility; 
(3) In order to establish if the market capitalisation can be affected by stakeholders' responsibility perception, a correlation between the two factors has been investigated. The submitted questionnaire shows a strong reliability of content; this is shown by the results of the Cronbach's alpha concerning the 170 proposed items (one for every tested dimension, multiplied for the 33 analyzed firms). The result is 0.993 for number 170 items.

\section{Analysis and Discussion of Results}

In order to give an answer to Q1, the sample has been asked to rank the perceived responsibility of various industries, considering firms playing in. As shown below (Table 3), the most responsible industries are: health and wellness $(P=3.743)$, food and beverage $(P=3.571)$, food service $(P=3.343)$, automotive $(P=3.257)$, and publishing $(P=3.257)$. Although the result concerning the health and wellness industries and food and beverage was foreseeable, it is interesting to notice that among the top sectors in terms of responsibility, the sample indicates the automotive industry. Probably this is due to the fact that, despite the industry is concerned with the production of goods which have a great environmental impact (Pastore, 2012), stakeholders recognize the efforts of its players from the point of view of pollution reduction and technology innovation, as well as from the point of view of social qualification of the local area.

Concerning Q2, the mean perception of responsibility has been considered. The aim has been to find if it was possible to talk about a certain correlation between firms' sustainability perception and their market capitalisation. Table 4 summarizes the outcomes and shows that firms had major results in terms of responsibility perception. Moreover, a correlation between the two variables has been found; it cannot talk about a strong correlation - the coefficient is 0.453 - but this result shows that the more a public company has a strong capitalization, the more the effort to be perceived as responsible by its stakeholder is.

Table 3

Degree of Perceived Sustainability of Tested Industries

\begin{tabular}{|c|c|c|c|c|c|c|c|c|}
\hline & Apparel & Jewellery & $\begin{array}{l}\text { Food and } \\
\text { beverage }\end{array}$ & Auto & Publishing & $\begin{array}{l}\text { Software and } \\
\text { IT }\end{array}$ & $\begin{array}{l}\text { Motion- } \\
\text { picture industry }\end{array}$ & $\begin{array}{l}\text { Home } \\
\text { furnishings }\end{array}$ \\
\hline Mean & 2.914 & 2.314 & 3.571 & 3.257 & 3.257 & 2.771 & 2.629 & 2.943 \\
\hline Median & 3 & 2 & 4 & 3 & 3 & 3 & 2 & 3 \\
\hline Mode & 3 & 2 & 3 & 4 & $3.0^{\mathrm{a}}$ & 3 & 2 & 3 \\
\hline Percentile 25 & 2 & 1 & 3 & 2 & 2 & 2 & 2 & 2 \\
\hline Percentile 50 & 3 & 2 & 4 & 3 & 3 & 3 & 2 & 3 \\
\hline \multirow[t]{2}{*}{ Percentile 75} & 4 & 3 & 4 & 4 & 4 & 3 & 3 & 3 \\
\hline & Grocery & $\begin{array}{l}\text { Telecommun } \\
\text { ications }\end{array}$ & $\begin{array}{l}\text { Hi tech } \\
\text { production }\end{array}$ & Applicances & Food service & $\begin{array}{l}\text { Health and } \\
\text { wellness }\end{array}$ & $\begin{array}{l}\text { Sporting } \\
\text { industry/sporting } \\
\text { firms }\end{array}$ & \\
\hline Mean & 2.971 & 2.6 & 2.6 & 3.086 & 3.343 & 3.743 & 3.143 & \\
\hline Median & 3 & 2 & 2 & 3 & 3 & 4 & 3 & \\
\hline Mode & 3 & 2 & 2 & $3.0^{\mathrm{a}}$ & 3 & 4 & 4 & \\
\hline Percentile 25 & 2 & 2 & 2 & 2 & 3 & 3 & 2 & \\
\hline Percentile 50 & 3 & 2 & 2 & 3 & 3 & 4 & 3 & \\
\hline Percentile 75 & 4 & 4 & 3 & 4 & 4 & 4 & 4 & \\
\hline
\end{tabular}

Note. ${ }^{\text {a }}$ There are more modes: The minor result has been considered.

Table 5 includes public companies with a responsibility perception mean higher than 2.97 points. It highlights how firms do not communicate enough their social values risk to be perceived less responsible than 
they really are. Evidence shows that this involvement in CSR can be considered as a driver of marketing communication in order to increase brand equity and to make the whole corporate communication homogeneous and coherent with the values and beliefs characterizing the corporate culture.

Table 4

Firms Capitalization and Sustainability

\begin{tabular}{|c|c|c|}
\hline Firm & Last market capitalisation (2013 mil euros) & Sustainability perception (mean) \\
\hline Luxottica & 14,663 & 3.4 \\
\hline Telecom & 9,164 & 2.7 \\
\hline Campari & 6,737 & 3.1 \\
\hline Fiat & 4,739 & 3.2 \\
\hline Pirelli & 4,118 & 2.98 \\
\hline Parmalat & 3,100 & 2.76 \\
\hline Tod's & 2,928 & 3.2 \\
\hline Autogrill & 2,209 & 2.95 \\
\hline Delonghi & 1,747 & 2.93 \\
\hline Res & 956 & 2.84 \\
\hline Amplifon & 838 & 2.95 \\
\hline Piaggio & 755 & 2.96 \\
\hline Indesit & 657 & 2.72 \\
\hline Geox & 564 & 3.3 \\
\hline Safilo & 411 & 2.77 \\
\hline L'espresso & 361 & 2.84 \\
\hline Mondadori & 277 & 2.9 \\
\hline Juventus Fc & 198 & 2.99 \\
\hline Poltr. Frau & 136 & 2.86 \\
\hline Damiani & 88 & 2.89 \\
\hline Basic Net & 83 & 3.07 \\
\hline Seat Pg & 74 & 2.73 \\
\hline Tiscali & 72 & 2.75 \\
\hline Piquadro & 71 & 2.78 \\
\hline Beghelli & 68 & 2.98 \\
\hline As Roma & 60 & 2.84 \\
\hline Sole 24 Ore & 47 & 2.9 \\
\hline Natuzzi & 44 & 2.84 \\
\hline Stefanel & 35 & 2.89 \\
\hline Ss Lazio & 28 & 2.78 \\
\hline Zucchi & 15 & 2.88 \\
\hline Centr.Latte & 15 & 3.1 \\
\hline
\end{tabular}

Table 5

Best Firms Sample Perception and Their Main Sustainability Activities

\begin{tabular}{|l|l|l|l|l|}
\hline $\begin{array}{l}\text { Company } \\
\text { sustainability } \\
\text { mean) }\end{array}$ & $\begin{array}{l}\text { Sustainability in the } \\
\text { web site }\end{array}$ & $\begin{array}{l}\text { Sustainability in the } \\
\text { annual report }\end{array}$ & $\begin{array}{l}\text { Principal } \\
\text { events/sponsorships/foundations }\end{array}$ & $\begin{array}{l}\text { Sustainability } \\
\text { communicated as brand } \\
\text { value }\end{array}$ \\
\hline Luxottica (3.4) & High visibility & $\begin{array}{l}\text { Sustainable } \\
\text { development } \\
\text { program }\end{array}$ & $\begin{array}{l}\text { Projects that allow to realize the } \\
\text { company's core values (respect, health } \\
\text { and personal and professional growth of } \\
\text { people, environmental protection, and } \\
\text { social development of the territory) }\end{array}$ \\
\hline
\end{tabular}


Table 5 continued

\begin{tabular}{|l|l|l|l|l|}
\hline $\begin{array}{l}\text { Company } \\
\text { (sustainability } \\
\text { mean) }\end{array}$ & $\begin{array}{l}\text { Sustainability in the } \\
\text { web site }\end{array}$ & $\begin{array}{l}\text { Sustainability in the } \\
\text { annual report }\end{array}$ & $\begin{array}{l}\text { Principal } \\
\text { events/sponsorships/foundations }\end{array}$ & $\begin{array}{l}\text { Sustainability } \\
\text { communicated as brand } \\
\text { value }\end{array}$ \\
\hline Fiat (3.2) & High visibility & $\begin{array}{l}\text { Sport sponsorships. Chrysler foundation } \\
\text { for charity local and global) }\end{array}$ & $\begin{array}{l}\text { Not directly: innovation, } \\
\text { ethical codes, social } \\
\text { development, and } \\
\text { employment }\end{array}$ \\
\hline Tod's (3.2) & Medium visibility & $\begin{array}{l}\text { Social commitment } \\
\text { and environment }\end{array}$ & $\begin{array}{l}\text { Colosseum renovation } \\
\text { commitment }\end{array}$ \\
\hline Campari (3.1) & High visibility & $\begin{array}{l}\text { Campari and CSR; } \\
\text { responsible drinking } \\
\text { and environment }\end{array}$ & $\begin{array}{l}\text { Campari Academy. Eco Campari } \\
\text { initiatives. Hogar Exaltation } \\
\text { (refuge for children) }\end{array}$ & Not directly: ethic code \\
\hline $\begin{array}{l}\text { Centrale Latte } \\
\text { Torino (3.1) }\end{array}$ & High visibility & $/$ & $\begin{array}{l}\text { Educational area } \\
\text { for mothers and babies), health guide }\end{array}$ & $\begin{array}{l}\text { Directly through the } \\
\text { brand }\end{array}$ \\
\hline $\begin{array}{l}\text { Juventus FC } \\
\text { (2.99) }\end{array}$ & High visibility & $\begin{array}{l}\text { Fiat sustainability } \\
\text { report }\end{array}$ & $\begin{array}{l}\text { Hospital Gaslini } \\
\text { (children hospital) }\end{array}$ & $\begin{array}{l}\text { Directly (social and } \\
\text { ethical commitment) }\end{array}$ \\
\hline Beghelli (2.98) & Medium visibility & $\begin{array}{l}\text { Sustainability not } \\
\text { outline }\end{array}$ & $/$ & $\begin{array}{l}\text { Environmental } \\
\text { innovation }\end{array}$ \\
\hline Pirelli (2.98) & Low visibility & Sustainability report & $\begin{array}{l}\text { Pirelli foundation based on ethical } \\
\text { principles }\end{array}$ & $\begin{array}{l}\text { Value chain, corporate } \\
\text { governance, and } \\
\text { employment }\end{array}$ \\
\hline Bialetti (2.9) & High visibility & $\begin{array}{l}\text { Health, security, and } \\
\text { environment }\end{array}$ & $\begin{array}{l}\text { Support for the National Breast Cancer } \\
\text { Foundation (NBCF) }\end{array}$ & \begin{tabular}{l} 
Directly \\
\hline
\end{tabular} \\
\hline
\end{tabular}

\section{Conclusions}

Despite efforts spent to gather results, the tested sample should be wider in order to reach major statistical evidence. Moreover, the analysis has been carried out considering only one country.

From present research results, it emerges for all analyzed firms the inclusion of ethics, sustainable, and responsible aims for strategic objectives in the mission and in the corporate strategic plan they set up for pursuing their main and core business purposes. Especially in sectors with a strong impact on environment, like the automotive industry, perceiving the responsibility of firms' activities represents the impact they can have on stakeholders' judgment and choices. Moreover, responsibility policies have to come out naturally from the general business strategy. Accordingly, every company should provide a dedicated unit or committee or group involved in implementing the responsibility both strategically and at an operational level by pursuing more concrete activities. For this purpose, an external and internal consistent communication plan can help and could follow the structure below, planning borrowed from what is related to integrate marketing communication. Rules to consider can be defined by following communication planning steps (Casalegno, 2012; Duncan \& Ouwersloot, 2007):

- following analysis results directions;

- converting them in destination objectives. Main goals must be quantitative and valuable; they must be specific, on one hand, challenging, on the other hand;

- developing strategies and using benchmarking to do that;

- defining the right budget for communication spending.

The last step is about the evaluation of communication strategy effects; since it represents an investment, it will be useful to understand quantitative effects of it in advance. But what emerges as more common to all the companies' part of the sample is the fact that they all go beyond to the simple sense of responsibility as sum of communication and non-business oriented actions for the community. Through the study of the best practices 
and the analysis of this present research results, it can be possible to implement a model which combines brand and social concerns to have positive impact both on financials and the community itself. This can be effective, if nowadays both private and institutional investors are increasingly diversifying their portfolios by investing in companies that set industry-wide best practices with regard to sustainability. A concrete strategy for the corporate shared value can be considered as a chance in order to improve relationships with stakeholders, considering youth changing media attitudes.

Eventually, since the present research is focused on one country, next steps will consider a wider geographical area in order to build a more complete data analysis based on the perception of multinational firms' stakeholders, beyond their geographical location.

\section{References}

Aaker, D. A. (2004). Leveraging the corporate brand. California Management Review, 46(3), 6-18.

Aaker, D. A., \& McLoughlin, D. (2009). Strategic market management: Global perspectives. Chichester: John Wiley \& Sons.

Belch, G. E., \& Belch, M. A. (2009). Advertising and promotion: An integrated marketing communications perspective. New York: The McGraw-Hill.

Blombäck, A., \& Ramírez-Pasillas, M. (2012). Exploring the logics of corporate brand identity formation. Corporate Communications: An International Journal, 17(1), 7-28.

Candelo, E., Casalegno, C., \& Civera, C. (2014). Meanings and implications of corporate social responsibility and branding in grocer retailers: A comparative study over Italy and the UK. Handbook of Research on Retailer-Consumer Relationship Development. Hershey: IGI Global Inc.

Casalegno, C. (2012). Pubblicità: istruzioni per l'uso. Strategie, strumenti e tecniche in tempi di cambiamento (Integrated firm communication and PR: Instruction for the use). Milan: FrancoAngeli.

Christodoulides, G., \& Jevons, C. (2011). The voice of the consumer speaks forcefully in brand identity. Journal of Advertising Research, 51(1), 101-108.

Collesei, U., \& Ravà, V. (2008). La comunicazione d'azienda (Company communication). Turin: Isedi.

Cronin, J. J., \& Taylor, S. A. (1992). Measuring service quality: A reexamination and extension. The Journal of Marketing, 56(3), 55-68.

Demetriou, M., Papasolomou, I., \& Vrontis, D. (2010). Cause-related marketing: Building the corporate image while supporting worthwhile causes. Journal of Brand Management, 17(4), 266-278.

Duncan, T., \& Ouwersloot, H. (2007). Integrated marketing communications. Maidenhead: McGraw Hill.

Kuepfer, J., \& Papula, J. (2010). Corporate social responsibility-The dilemmas behind the popular concept and how to best address them. International Journal of Sustainable Society, 2(3), 291-305.

Lopez-De-Pedro, J. M., \& Rimbau-Gilabert, E. (2012). Stakeholder approach: What effects should we take into account in contemporary societies? Journal of Business Ethics, 107(2), 147-158.

Macleod, S. (2001). Why worry about CSR? Strategic Communication Management, 5(5), 8-9.

Mohr, L. A., Webb, D. J., \& Harris, K. E. (2001). Do consumers expect companies to be socially responsible? The impact of corporate social responsibility on buying behavior. Journal of Consumer Affairs, 35(1), 45-72.

Pastore, A. (2012). Green marketing e mobilità sostenibile (Green marketing and sustainable mobility). Mercati e competitività, 2 , $13-20$.

Porter, M. E., \& Kramer, M. R. (2006). Strategy and society: The link between competitive advantage and corporate social responsibility. Harvard Business Review, 85(12), 78-92.

Porter, M., \& Kramer, M. (2011). Creating shared value. How to reinvent capitalism and unleash a wave of innovation and growth. Harvard Business Review, 89(1/2), 62-77.

Rebollo, J. F. V., \& Baidal, J. A. I. (2003). Measuring sustainability in a mass tourist destination: Pressures, perceptions and policy responses in Torrevieja, Spain. Journal of Sustainable Tourism, 11(2-3), 181-203.

Rep Trak 100-Global Report. (2013). New York: Reputation Institute.

Romoli Venturi, R., Casalegno, C., \& De Palma, P. (2014). Comunicazione integrata e PR: istruzioni per l'uso (Firm communication and PR: Instructions for the use). Milano: Franco Angeli. 
Schianetz, K., \& Kavanagh, L. (2008). Sustainability indicators for tourism destinations: A complex adaptive systems approach using systemic indicator systems. Journal of Sustainable Tourism, 16, 601-628.

Schultz, D. E., Tannenbaum, S. I., \& Lauterborn, R. F. (1994). The new marketing paradigm: Integrated marketing communications. Chicago: McGraw Hill Professional.

Torres, A., Bijmolt, T., Tribo, J., \& Verhoef, P. (2012). Generating global brand equity through corporate social responsibility to key stakeholders. International Journal of Research in Marketing, 29(1), 13-24.

Vallaster, C., Lindgreen, A., \& Maon, F. (2012). Strategically leveraging corporate social responsibility: A corporate brand perspective. California Management Review, 54(3), 34-60.

Werther, W. B., \& Chandler, D. (2005). Strategic corporate social responsibility as global brand insurance. Business Horizons, 48(4), 317-324.

Wheeler, A. (2012). Designing brand identity: An essential guide for the whole branding team. New York: John Wiley \& Sons. 